\title{
PSYCHOSOCIAL PERSONALITY DEVELOPMENT: CONTINUITY AND CHANGE IN ADOLESCENT, YOUTH AND ADULT AGE
}

UDC: $159.922 .8+[159.922 .27-053.6]$

\section{Shamne Anzhelika}

Dr. in Psychology, Associate Professor, Professor of the Department of Psychology, department of psychology, National University of Life and Environmental Sciences of Ukraine, Kiev (Ukraine)

ORCID ID: https://orcid.org/0000-0003-1541-6079

\begin{abstract}
The article presents the results of the comparison of the variability of the psychosocial development of the personality in the adolescent, youth and adult age. At the first stage of the empirical study, the types of development in adolescence and youth age. Personality (motivation, value orientations, focus, communicative features), subject (autonomy, self-regulation, locus of control), as well as social and behavioural (distinctive features of social functioning) characteristics were used as typing criteria. The types of the psychosocial development of adolescents and youths are interpreted as constructive, nonconstructive and destructive models of coming of age. At the second stage of the study the theoretical generalization of the types of personality existing in psychology and strategies of personality functioning during the period of adult age. The analysis is based on the theories of A. Adler, K. Horney, D. Marsh, E. Desci and R. Rayen, E. Fromm et al.

The types of the psychosocial development of adolescents and youths was compared with variants (types, patterns) of the development in adulthood. The dynamics and continuity of the types of the psychosocial development and strategies for functioning adolescents, youths and adults were determined. It was revealed that the main features of continuity can be found along the lines of constructive or nonconstructive development, focus on oneself or other people, self-sufficiency or dependence on the milieu and circumstances. The process of typing of the psychosocial development is the result of the integration of traits of the personality and the way it functions (behaves), which is inherent to it. The factors of that process were identified: regulation by the personality of his/her behavior and activities and his/her position in the system of relationships. The type of the psychosocial development is a complex structural and functional unity. The crystallization of that type from the adolescent age to adulthood is a targeted and logical process associated with the emergence of the self-concept, the ability to self-determination and self-
\end{abstract}


regulation mechanisms in the adolescent age. The article emphasizes the importance of prevention and correction of the preconditions of non-constructive development models.

Keywords: type of the psychosocial development, adolescent age, young age, adult age, personality, continuity of development, locus of control, focus on oneself (on people), (non) constructive (destructive) development.

\section{Introduction.}

The way to handle the problem of individualization of the personality development is the identification of the general, the typical and the individual, as well as the individually psychological and the socio-typical in that development. It is therefore relevant to research the substance and continuity of variably typological forms of the personality development during the main periods of that development, i.e. during childhood, adolescence and adulthood.

In the previous publications, the results of an empirical study of the types of the psychosocial development in adolescent (a sample of 455 schoolboys of 12 to 16 years of age) (Shamne, 2015 ) and youths (a sample of 430 students of 20 to 23 years of age) (Shamne, 2017) were presented.

\section{Research methods.}

A set of valid diagnostic techniques was used: the Biographical Questionnaire (BIV); 16PF Questionnaire by R. Cattell (the A, H, E, $\mathrm{Q}_{2}, \mathrm{~N}$ and $\mathrm{L}$ scales); the questionnaire «The person orientation» by V. Smekal - M. Kucher (QPO); the Personal (semantic) Differential (PD) method (an adapted version in the St. Petersburg Psychoneurological Research Institute named after V.M. Bekhterev; School Anxiety Question- naire (B. N. Phillips); the test-questionnaire on personality self-attitude «Self-Relationship» by V. Stolin; Author's test-questionnaire «Psychosocial Development of Adolescents» (PDA) and Author's Questionnaire «Crisis of adolescence» (factors: crisis of relations, crisis of activity) (Shamne, 2015); Test of sense-of-life orientation (SLO) by D. Leontyev; «Questionnaire on the level of subjective control» (LSC) by E.F. Bazhin, E.A. Golynkina and A. M. Etkind; The Personal Orientation Inventory (POI); the Thomas-Kilmann Conflict Mode Instrument (TKI); the technique of T. Leary «Diagnostics of interpersonal relations» (DIR) (Octants I-VIII); «Individualism -Collectivism Indicators» by L. G. Pochebut; Coping Strategy Indicator (CSI) by J. Amirkhan; «Coping behavior in stressful situations» technique (S. Norman, D. Endler, D. James, M. Parker, an adapted version by T. Kryukova); Sociometric method. As research tools, the method of modelling, the variable patterns method, the comparative method and the method of genetic analysis were used. Personality (motivation, value orientations, focus, communicative features), subject (autonomy, self-regulation, locus of control), as well as social and behavioural (distinctive features of social functioning) characteristics were 
used as typing criteria.

Statistical data processing was carried out using the factor analysis. In both age groups, the four-factor model had significant meaningful and statistical benefits $(59.6 \%$ and $49.96 \%$ of the sample data variance, respectively). On the basis of those factor models, the types of the psychosocial development in the adolescent (autonomously self-sufficient, internally dominant, friendly dependent, frustrated/crisisstricken) and youth (harmonious, dominantsubject, depending adaptive, disintegrated) age were described.

\section{Aim and Tasks}

The comparison of the substance of the main types (patterns) of the psychosocial development in the in the adolescent, youth and adult age, as well as determining their dynamics and continuity is the purpose of this phase of the study. The aim involves coping with the following tasks: 1) to explore the typological picture development in the in the adolescent, youth and adult age; 2) compare these types of development; 3) substantiate dynamics and continuity these types.

The idea of «dynamic typology» in psychology is to recognize the variability and, at the same time, the continuity of the basic features of the personality type and those of the pattern of functioning (behaviour) in ontogeny. The combination of typological and dynamic approaches is a heuristic resource for modelling the processes of the individual development. We assumed that the

individualization

and

typing

(«crystallization») (Magnusson, 1996) of the psychosocial development in the period from the juvenile age to adulthood is a targeted and logical process. In the adolescent and youth age, the structure of the basic traits of the personality and the pattern of functioning shaped on the latter's basis integrate into a more or less stable type (pattern) of the psychosocial development of the personality. That type (pattern), in turn, predetermines the further deployment of a «scenario» for life and development of the personality in adulthood.

The juvenile age is sensitive as to the type of the psychosocial development. According to L. Vygotskyi, it is precisely in the adolescent age that a qualitatively new type of development in ontogeny appears. Its appearance is related, firstly, to the emergence of the so-called «tertiary (after heredity and environment) features», i.e. reflection, self-awareness, self-formation and, secondly, to the action of «the law of transition from external to internal processes», which «transforms the development process, changes its structure and functions». Consequently, in the adolescent age, the personality of a teenager enters the developmental drama as a «new, qualitatively distinct factor» (Vygotskyi, 1984).

As the main criterion of the meaningful psychosocial development, we examined the efficiency of solving by an individual of coming-ofage problems, viz. the «dichotomies of development» (Kapustin, 2014), in particular, finding by 
the individual of a balance (compromise): 1) between the tendency to assert oneself (the desire of superiority) and at the same time the need to be accepted by other people; 2) between the need for self-actualization and the simultaneous aspiration to honour conventions; 3) between the awareness of personal responsibility for self-determination and at the same time taking into account the real possibilities that are dictated by the biological and social circumstances of life.

The types of the psychosocial development in the adolescent and youth age are represented by diverse variations of constructive (the «autonomously self-sufficient» and «harmonious» types), non-constructive (the «internally dominant»/《dominant-subject» and «friendly dependent»/«depending adaptive» types) and destructive development (the «frustrated/crisis-stricken» and «disintegrated» types) (Fig. 1).

\section{Discussion.}

The substance of the constructive development in the adolescent and youth age is represented by the «autonomously self-sufficient» and «harmonious» types (in the group of juveniles, that factor explains $18.51 \%$ of the data variance while in the group of adolescents it does $19.52 \%$ ). The continuity of those types is evidenced by their common characteristics: autonomy, social activity, subjective well-being, sociability, spontaneity, internal locus of control, reliance on one's own values and beliefs, the ego power, adequate self-appraisal; proactive stance, orientation towards cooperation with other people, benevo-

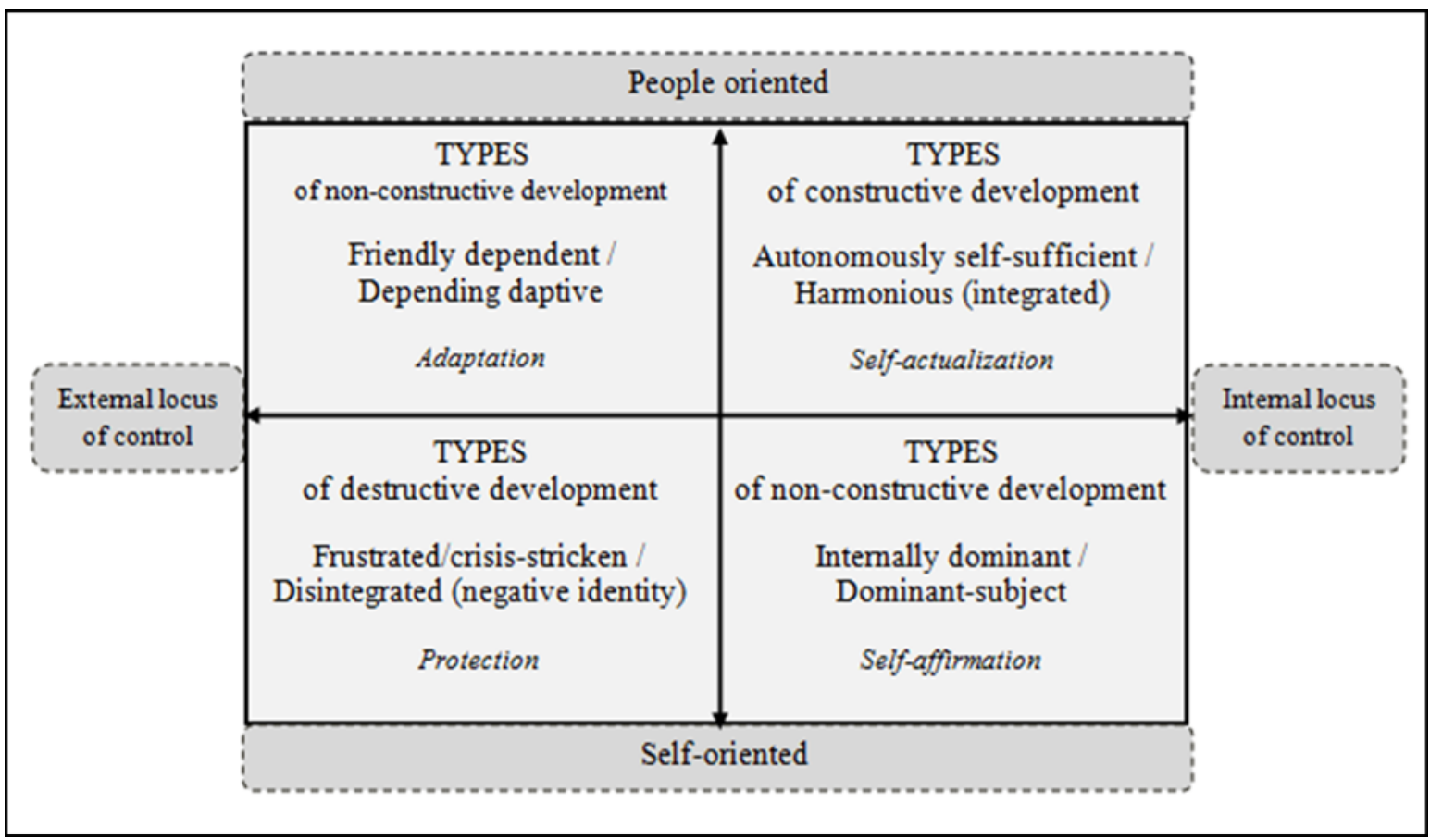

Fig. 1 The continuity of the types of the psychosocial development in the adolescent and youth age 
lence, humanistic orientation and social interest (Table 1).

However, there are significant differences autonomy, integration, tendencies towards selfactualization.

The internally dominant/dominant-subject

Table 1

Content of constructive development in adolescent and youth age

\begin{tabular}{|c|c|c|}
\hline Factor's name & Basic components of the factor and their weight & Weight \\
\hline $\begin{array}{l}\text { Autonomously self } \\
\text {-sufficient } \\
\text { (adolescents) }\end{array}$ & $\begin{array}{l}\text { Self-sympathy }(0.695) \text {, crisis of the individual }(0.621) \text {, internal locus of life } \\
(0.605) \text {, autonomy }(0.599) \text {, internal locus of control-ego }(0.594) \text {, crisis of the } \\
\text { personality }(0.566) \text {, subjective well-being }(0.532) \text {, Factor A }(0.529) \text {, Factor E } \\
(0.516) \text {, Factor H }(0.507) \text {, Octant V }(-0.478) \text {, spontaneity }(0.470) \text {, Octant II } \\
(0.443) \text {, dominance }(0.474) \text {, SOZAKT (test BIV) }(-0.469) \text {, sociability }(0.468) \text {, com- } \\
\text { petition }(0.452) \text {, autonomy }(0.436) \text {, activity }(0.418) \text {, extraversion }(0.406) \text {, Factor } \\
\text { Q2 }(0.361)\end{array}$ & 18,5 \\
\hline $\begin{array}{l}\text { Harmonious } \\
\text { (integrated) } \\
\text { (youths) }\end{array}$ & $\begin{array}{l}\text { Negative ego-identity }(-0.806) \text {, the result of living }(0.801) \text {, internal locus of con- } \\
\text { trol-ego }(0.762) \text {, goals in life }(0.754) \text {, externality }(-0.736) \text {, subjective well-being } \\
(0.681) \text {, internal locus of life }(0.636) \text {, ICHSTK }(-0.623) \text {, sociability }(0.534) \text {, sponta- } \\
\text { neity (0.496), material values }(-0.490) \text {, ERZIEN (test BIV) }(-0.489) \text {, Octant II } \\
(0.437) \text {, flexibility }(0.431) \text {, Octant IV }(-0.409) \text {, Ic. }(0.410) \text {, focus on the interaction } \\
(0.410) \text {, general anxiety }(-0.399)\end{array}$ & \\
\hline
\end{tabular}

between them that reflect the age-specific dynamics of development. For the «autonomously selfsufficient» type, the key features are perseverance, commitment to achieving goals and influence on others. It illustrates the formation of the key components of the subject of activity, viz. internality, self-regulation, motivation for achievement. For the «harmonious» type, the key features are self-sufficiency, self-sympathy and trust in the world. It illustrates the formation of the key components of the subject of living, viz.
(13.03\% and $16.56 \%$ variability) and friendly dependent/socially adaptive types $(11.63 \%$ and $12.23 \%)$ are the variants of the non-constructive development.

The following characteristics are typical of representatives of the «internally dominant» and «dominant-subject» types: dominant style of communication, tendency towards rivalry, autonomy, focus on oneself (individualism), independence from the group, internality in various 
spheres of life, active coping behaviour strategies, etc. (Table 2). egocentrism, pragmatism, the desire to dominate and the absence of deep, close relationships con-

Table 2

Content of non-constructive development in adolescent and youth age (1)

\begin{tabular}{|c|c|c|}
\hline Factor's name & Basic components of the factor and their weight & Weight \\
\hline $\begin{array}{l}\text { Internally dominant } \\
\text { (adolescents) }\end{array}$ & $\begin{array}{l}\text { Octant III (0.798), Octant I }(0.793) \text {, Octant II }(0,768) \text {, internality (total) }(0.682) \text {, } \\
\text { Octant VIII }(0.671) \text {, internality (interpersonal) }(0.624) \text {, avoidance }(-0.614) \text {, } \\
\text { emotions (coping) }(0.569) \text {, collectivism }(-0.560) \text {, dominance }(0.494) \text {, Octant IV } \\
\text { (0.466), problem solving (coping) }(0.431) \text {, individualism }(0.452) \text {, formal criteri- } \\
\text { on according to sociometry }(0.399) \text {, crisis of the personality }(0.39)\end{array}$ & 13,0 \\
\hline $\begin{array}{l}\text { Dominant-subject } \\
\text { (youths) }\end{array}$ & $\begin{array}{l}\text { Competition }(0.709) \text {, Octant I }(0.693) \text {, avoidance }(-0.669) \text {, } \\
\text { Octant III }(0.642) \text {, autonomy }(0.636) \text {, internality (achievements) }(0.575) \text {, inter- } \\
\text { nality (total) }(0.569) \text {, internality (interpersonal) }(0.529) \text {, SOZAKT (test BIV) (- } \\
0.508) \text {, Octant II (0.508), material values (0.454), internality (family) }(0.443) \text {, } \\
\text { crisis of the individual }(-0.433) \text {, focus on business (problem) }(0.431) \text {, In. } \\
(0.426) \text {, individualism }(0.416) \text {, problem solving (coping) }(0.403)\end{array}$ & 16.56 \\
\hline
\end{tabular}

However, the youths of the «dominantsubject» type tend to have no traits inherent in the «internally dominant» type of adolescents such as empathy, responsibility in relations with people, aspiration for activities that are beneficial to others. Those adolescents are characterized by a greater focus on achievement (money, career, power) and the influence on the milieu (leadership in the milieu), more focus on themselves and on material security, as well as more pronounced offensive behavior strategies. The dynamics of those types shows that a complete mature identity develops in unity with humanism, the acceptance of others and the development of spiritual values. The pronounced individualism, stitute risks for the constructive psychosocial development.

The «friendly dependent» type of adolescents and the «depending adaptive» type of youths are similar to each other by the following characteristics: orientation towards others, collectivism, standard behaviour, social activity, benevolence and focus on interaction. Those traits are favourable for the development of personality in the adolescent age. However, in youth age, they tend to lead to complications in shaping the identity. The low level of autonomy, selfunderstanding and popularity among peers, as far as the representatives of the «depending adaptive» type are concerned, testify to the frustrated 
need for self-affirmation and social activity in variability) and the "disintegrated» one in youth youth age (Table 3$)$.

$(9.681 \%)$. The factor weight of the destructive

Table 3

\section{Content of non-constructive development in adolescent and youth age (2)}

\begin{tabular}{|c|c|c|}
\hline Factor's name & Basic components of the factor and their weight & Weight \\
\hline $\begin{array}{l}\text { Friendly depend- } \\
\text { ent (adolescents) }\end{array}$ & $\begin{array}{l}\text { Friendliness }(0.701) \text {, focus on the interaction }(0.629) \text {, Factor Q2 }(-0.582) \text {, focus on } \\
\text { business }(0.529) \text {, autonomy }(-0.492) \text {, social activity }(E)(-0.482) \text {, crisis of the per- } \\
\text { sonality }(-0.471) \text {, collectivism }(0.465) \text {, support search (coping) }(0.457) \text {, Factor A } \\
(0.457) \text {, Octant VI }(0.447) \text {, externals ego }(0.445) \text {, material values }(-0.427) \text {, } \\
\text { evaluation }(S)(0.422) \text {, Octant V }(0.415) \text {, spontaneity }(-0.415) \text {, adaptation }(0.401) \text {, } \\
\text { Octant VII }(0.400)\end{array}$ & 11,6 \\
\hline $\begin{array}{l}\text { Depending adap- } \\
\text { tive (youths) }\end{array}$ & $\begin{array}{l}\text { Octant VII }(0.903) \text {, self-understanding }(-0.807) \text {, adaptation }(0.707) \text {, Octant VIII } \\
(0.618) \text {, A }(0.566) \text {, crisis of the personality }(-0.470), Q_{2}(-0.469) \text {, flexibility }(0.450) \text {, } \\
\text { autonomy }(-0.445) \text {, compromise }(0.398) \text {, Octant VI }(0.448) \text {, Octant II }(-0.420) \text {, so- } \\
\text { ciability }(0.413) \text {, collectivism }(0.400) \text {, formal criterion according to sociometry (- } \\
0.390)\end{array}$ & \\
\hline
\end{tabular}

The substance of the destructive development is represented by the «frustrated/crisisstricken» type in the adolescent age (the $16.54 \%$ type in youth is significantly lower, which indirectly bears witness to an increase in the stabilization tendencies of development and the end of the critical juvenile period (Table 4).

Table 4

\section{Content of destructive development in adolescent and youth age}

\begin{tabular}{|c|c|c|}
\hline Factor's name & Basic components of the factor and their weight & Weight \\
\hline $\begin{array}{l}\text { Frustrated } \\
\text { /crisis-stricken } \\
\text { (adolescents) }\end{array}$ & $\begin{array}{l}\text { Process of living }(-0.608) \text {, external locus of life }(0.589) \text {, crisis of the personality } \\
(0.585) \text {, orientation in time }(-0.584) \text {, PSYKON (test BIV) }(0.583) \text {, ERZIEN (test BIV) } \\
(0.566) \text {, N (0.565), FAM }(0.534) \text {, material values }(0.515) \text {, negative ego-identity } \\
(0.505) \text {, internal locus of control-ego }(-0.494) \text {, the values of life }(-0.492) \text {, evaluation } \\
\text { (S) }(-0.470) \text {, focus on business (problem) (-0.454), SOZLAG (test BIV) (0.433), } \\
\text { emotions (coping) }(0.428) \text {, problem solving (coping) (-0.411), avoidance (0.403), } \\
\text { internality (total) }(-0.403) \text {, dominance }(-0.402) \text {, general anxiety }(0.401)\end{array}$ & 16,5 \\
\hline $\begin{array}{l}\text { Disintegrated } \\
\text { (negative identi- } \\
\text { ty) } \\
\text { (youths) }\end{array}$ & $\begin{array}{l}\text { Octant VI }(0.733) \text {, sociability }(0.701) \text {, values }(-0.698) \text {, Octant V }(0.570) \text {, negative ego } \\
\text {-identity }(0.534) \text { view of human nature }(-0.514) \text {, focus on the interaction }(-0.471) \text {, } \\
\text { creativity }(-0.457) \text {, SOZAKT (test BIV) }(0.454) \text {, spontaneity }(-0.441) \text {, subjective well- } \\
\text { being }(-0.441) \text {, crisis of the individual }(0.433) \text {, self-sympathy }(-0.430) \text {, orientation in } \\
\text { time }(-0.427) \text {, S }(-0.417) \text {, general anxiety }(0.417) \text {, SOZLAG (test BIV) }(0.390) \text {, crisis of } \\
\text { the personality }(0.39)\end{array}$ & 9,68 \\
\hline
\end{tabular}


The «disintegrated» type is an enhanced version of the «frustrated/crisis-stricken» type. Both are similar to each other by the following criteria: dissatisfaction with oneself (low selfappraisal, negative attitude to oneself); the «negative identity» syndrome (externality, low level of understanding of the authorship of one's own life); heightened feeling of frustration, pronounced tension in personal and social situations, difficulties of social adaptation. The differences between those types lie in the principal development problem. In adolescents, it is the problem of the formation of the subject agency of activities (externality, low self-regulation of activities, etc.). In youths, the main problem area is the formation of the subject agency (authorship) of life.

During the second stage of the study, we systematized the known types of development in adulthood and compared them with the preliminary empirical results (Table 5). As shown by the

Table 5

The comparison of the types (patterns) of the psychosocial development in the juvenile and adolescent age with the development typologies in adulthood

\begin{tabular}{|c|c|c|c|c|}
\hline Authors & \multicolumn{4}{|c|}{ The types of the development } \\
\hline $\begin{array}{l}\text { Juvenile/adolescent } \\
\text { (the types of the devel- } \\
\text { opment ) }\end{array}$ & $\begin{array}{l}\text { Autonomously self- } \\
\text { sufficient/harmonious }\end{array}$ & $\begin{array}{l}\text { Internally dominant/ } \\
\text { dominant-subject }\end{array}$ & $\begin{array}{l}\text { The friendly depend- } \\
\text { ent /socially adap- } \\
\text { tive }\end{array}$ & $\begin{array}{l}\text { Frustrated-crisis- } \\
\text { stricken } \\
\text { /disintegrated }\end{array}$ \\
\hline $\begin{array}{l}\text { A. Adler (Adler, 1993) } \\
\text { (personality types) }\end{array}$ & Productive type & Dominant type & Dependent type & Appropriating type \\
\hline $\begin{array}{l}\text { K. Horney (Horney, } \\
\text { 1995) (neurotic types) }\end{array}$ & - & $\begin{array}{l}\text { Aggressive type: } \\
\text { against people }\end{array}$ & $\begin{array}{l}\text { Compliant type: } \\
\text { orientation towards } \\
\text { people }\end{array}$ & $\begin{array}{l}\text { Alienated type: } \\
\text { orientation } \\
\text { from people }\end{array}$ \\
\hline $\begin{array}{l}\text { E. Fromm (Fromm, 1990) } \\
\text { (types of social character) }\end{array}$ & Productive type & $\begin{array}{l}\text { Narcissistic type (against } \\
\text { love) }\end{array}$ & $\begin{array}{l}\text { Symbiotic type } \\
\text { (against } \\
\text { independence) }\end{array}$ & $\begin{array}{l}\text { Necrophilia (against } \\
\text { biofilia) }\end{array}$ \\
\hline $\begin{array}{l}\text { I. Yegorycheva } \\
\text { (Yegorycheva, 1999) } \\
\text { (types of orientation) } \\
\end{array}$ & The humanistic type & $\begin{array}{l}\text { Selfish type of } \\
\text { orientation }\end{array}$ & Socio-centric type & Negativistic type \\
\hline $\begin{array}{l}\text { D. Caprara (Caprara, } \\
\text { 2003) (personality types) }\end{array}$ & \multicolumn{2}{|c|}{ Adaptive type } & $\begin{array}{l}\text { Type with high } \\
\text { control type }\end{array}$ & Neurotic type \\
\hline $\begin{array}{l}\text { E. Deci, R. Ryan (Deci, } \\
\text { Ryan, 2004) (types of } \\
\text { orientation) }\end{array}$ & \multicolumn{2}{|c|}{ Autonomous orientation } & $\begin{array}{l}\text { Subordinated } \\
\text { orientation }\end{array}$ & $\begin{array}{l}\text { Impersonal } \\
\text { orientation }\end{array}$ \\
\hline $\begin{array}{l}\text { J. Loevinger (Loevinger, } \\
\text { 1976) (types of Ego) }\end{array}$ & Conscious & Autonomous & Conformal & $\begin{array}{l}\text { Self-defending, } \\
\text { impulsive }\end{array}$ \\
\hline $\begin{array}{l}\text { T. Tytarenko (Tytarenko, } \\
\text { 2000) (types of life world) }\end{array}$ & Relativistic worldview & $\begin{array}{l}\text { Egocentric } \\
\text { (focus on self) }\end{array}$ & $\begin{array}{l}\text { Conformal, } \\
\text { normative }\end{array}$ & - \\
\hline $\begin{array}{l}\text { J. Marcia (Marcia, 1966) } \\
\text { (identity types) }\end{array}$ & Accomplished identity & Moratorium & Borrowed identity & Diffuse identity \\
\hline $\begin{array}{l}\text { N. Kharlamenkova } \\
\text { (Kharlamenkova, 2007) } \\
\text { (life strategy) }\end{array}$ & Constructive life strategy & Dominant life strategy & $\begin{array}{l}\text { Dependent life strat- } \\
\text { egy }\end{array}$ & $\begin{array}{l}\text { Strategy of self- } \\
\text { suppression }\end{array}$ \\
\hline
\end{tabular}


theoretical analysis, psychologists use different terms (types of personality, types of behaviour, those of orientation, social character, identity, adaptation, development strategies, etc.). However, it is always a question of the general direction of the development and functioning (behaviour) of a person, which direction defines the essence of the latter's individuality.

The autonomously self-sufficient/ harmonious types of adolescents and youths generally match the productive (Fromm, 1990; Adler, 1993), autonomous (Deci, Ryan, 2004), conscious (Loevinger, 1976) type with a humanistic orientation (Yegorycheva, 1999), accomplished identity (Marcia, 1966), relativistic worldview (Tytarenko, 2000), high level of social adaptation (Caprara, 2003) and the constructive life strategy (Kharlamenkova, 2007).

Consequently, the main tendency of the constructive psychosocial development in the period from adolescent age to adulthood is the acquisition of psychosocial integrity, accomplished identity and, ultimately, self-actualization. The favourable resources for the development of the mature identity in adulthood are such qualities of adolescents and youths as autonomy, social activity, personalization in intimate-personal communication, internal locus of control, orientation towards spiritual values, positive attitude to oneself and subjective well-being.

The main psychological problems of the non-constructive types become more profound in adulthood. The internally dominant/dominant- subject types of development can transform into dominant (Adler, 1993), narcissistic (Fromm, 1990), aggressive (K. Horney, 1995), autonomous (Deci, Ryan, 2004; Loevinger, 1976) type with the selfish orientation (Yegorycheva, 1999; Tytarenko, 2000) and the dominant life strategy (Kharlamenkova, 2007). This is a personality, which is oriented only to himself or herself and his or her own goals and which is characterized by fixation on dominance over others, aspiration for superiority and rivalry, high assertiveness, selfishness, and the desire to make use of other people.

The friendly dependent/socially adaptive types are described in psychology, with certain variations, as dependent (Adler, 1993; Kharlamenkova, 2007), symbiotic (Fromm, 1990), compliant (K. Horney, 1995), conformal (Tytarenko, 2000; Loevinger, 1976), socio-centric (Yegorycheva, 1999), subordinated (Deci, Ryan, 2004) type with high control (Caprara, 2003), borrowed identity (Marcia, 1966) and the dependent life strategy (Kharlamenkova, 2007).

In adults, based on the friendly dependent/ socially adaptive types, there functions a dependent, non-self-sufficient personality oriented in a standard way. It is characterized by conformal behavior, search for social support, hyper-social mindset, dependence on circumstances and opinions of others, high affiliation level, heightened feeling of commitment, control over one's behaviour and emotions, low level of self-actualization. Consequently, the non-constructive devel- 
opment of personality in adulthood is actually an adaptation activity, which is effected on the basis of either dominance (desire for superiority, hyposocial mindset, individualism) or conformism (search for social support, hyper-social mindset, dependence). The leading orientation of behavioural activity of the non-constructive types in adulthood is a pronounced desire to either conquer the milieu or obey the milieu. In both cases, that orientation has a pseudo-compensatory character.

The «disintegrated» and «frustrated/crisisstricken» types of adolescents and youths generally match the non-productive, appropriating (Adler, 1993), alienated (K. Horney, 1995), «rebellious» (Fromm, 1990), self-defending, impulsive (Loevinger, 1976), neurotic (Caprara, 2003) type with the impersonal orientation (Deci, Ryan, 2004), negativistic type (Yegorycheva, 1999), diffuse identity (Marcia, 1966) and the strategy of self-suppression (Kharlamenkova, 2007).

Both during coming-of-age and during adulthood, the destructive development is associated with such traits as externality, pronounced pragmatism (focus on material values), fatalism, dissatisfaction with life, dependency, passive coping strategies, deformed self-concept, low self -appraisal, high sensitivity to rejection, shortage of social skills, selfish orientation, distrust of the world and people.

So, as the analysis showed, there is a certain similarity and continuity of the types of de- velopment and functioning in the adolescent/ youths age and in adulthood. This bears witness to the fact that the process of individualization of development is a logical and targeted process characterized by irreversibility, continuity and teleological nature. The mechanisms and determinants of that process require further research. However, we can assume that during coming-ofage (in persons 12 to 18 years old), the basic traits of personality (its structure) and individual style of functioning (acts of behaviour, choices, actions, every-day relationships and activities) operate in the manner of a ring-connection mechanism. Gradually, those structural and functional relationships crystallize into a more or less stable basis for the deployment of a «development scenario» in adulthood. There are therefore grounds to believe that the adolescent and youth age is sensitive and decisive as to the crystallization of a development type and the «choice» of a development scenario (life) in adulthood. On the other hand, the psychosocial development in that period is characterized by a fundamental incompleteness and openness to various possibilities and influences. That development has great plasticity and variability, which determine the potential for the implementation of various forms of behaviour and development in ontogeny.

Conclusions. The type of the psychosocial development is a complex structural and functional unity, which is shaped in ontogeny by means of the interconnection of the type of personality and functioning thereof (behaviour). The 
crystallization of that type from the adolescent age to adulthood is a targeted and logical process associated with the emergence of the selfconcept, the ability to self-determination and selfregulation mechanisms in the adolescent age.

As shown by the analysis, the main determinants of the crystallization of a certain type of the personality development in the period from the adolescent age to adulthood are two groups of internal factors: 1) regulation of behaviour and activity (locus of control; autonomy/dependence; orientation towards internal criteria (values, beliefs) or external ones (social approval, norms); self-reliance or seeking support in solving one's problems, etc.; 2) position in the system of relationships (collectivism/individualism, benevolence/aggressiveness, selfish/humanistic orientation; conformism/non-conformism; focus on individual achievement or group interests, etc.).

The results of the comparison of the types of development and strategies of personality functioning during the three age periods (adolescent, youth and adults) have shown that there is a certain meaningful similarity and continuity between them. The main features of continuity can be found along the lines of constructive (harmonious type) or non-constructive (disharmonious type) development, orientation towards oneself or towards other people, selfreliance or dependence on the milieu and circumstances. There are grounds to believe that the adolescent age is sensitive to the «choice» of one or another direction of development in adulthood.
Therefore, psychological support, prediction and correction of non-constructive and destructive manifestations of the development in the adolescent and youth age, with the age-specific and individual characteristics of the youth taken into account, are practically significant.

\section{References :}

Adler, A. (1993) Praktika i teorija individual'noj psihologii [The practice and theory of individual psychology]. Moscow: Pragma [in Russian].

Vygotskij, L. S. (1984) Sobranie sochinenij: V 6-ti t. T. 4. Detskaja psihologija [Collected Works: In 6 t. T. 4. Child Psychology]. Moscow: Pedagogika [in Russian].

Egorycheva, I. D. (1999) Lichnostnaja napravlennost' podrostka i metod ee diagnostiki [The personal orientation of the adolescent and the method of diagnosis]. Mir psihologii. The world of psychology, 1 (17), 264277 [in Russian]

Kaprara, Dzh. \& Servon, D. (2003) Psihologija lichnosti [Psychology of Personality]. St. Petersburg: Peter [in Russian].

Kapustin, S.A. (2014) Kriterii normalnoi i anomalnoi lichnosti v psikhoterapii i psikhologicheskom konsultirovanii [Criteria for normal and abnormal personality in psychotherapy and psychological counseling]. Moscow: Kogito-Tsentr [in Russian].

Titarenko, T. M. (2000) Nespromozhnist' do zhittevogo viboru: sproba osobistisnoï tipologizaciï [Failure to make a living choice: an attempt to personalize typology]. Naukovi studiï iz social'noï ta politichnoï psihologiï: zbirnik statej - Scientific Studies on Social and Political Psychology: a collection of articles, 2(5), 94-103 [in Ukrainian]. 
Fromm, Je. (1990) Imet' ili byt' [Have or to be]. Moscow: Progress [in Russian]

Harlamenkova, N. E. (2007) Samoutverzhdenie podrostka [Self-assertion of a teenager]. Moscow: RAS [in Russian].

Horni, K. (1995) Nashi vnutrennie konflikty. Konstruktivnaja teorija nevroza [Our internal conflicts. Constructive theory of neurosis]. Psihoanaliz i kul'tura : izbrannye trudy K. Horni i Je. Fromma. - Psychoanalysis and Culture: Selected Works by K. Horney and E. Fromm. Moscow: Jurist [in Russian].

Shamne, A.V. (2015) Kontynuum osobystisno-sub'jektnykh vlastyvostej jak chynnyk indyvidualizaciji psykhosocialjnogho rozvytku [Continuum of personalitysubjective properties as a factor of individualization of psychosocial development]. Aktualjni problemy psykhologhiji: zbirnyk naukovykh prats Instytutu psykholohii imeni H.S. Kostiuka NAPN Ukrainy Actual problems of psychology: collection of scientific works of G. S. Kostiuk Institute of Psychology, NAES of Ukraine, 10 (27), 633-645 [in Ukrainian].

Deci, E. L. \& Ryan, R. M. (2000) The 'what' and 'why' of goal pursuits: human needs and the self-determination of behavior. Psychological Inquiry, 11 (4), 227-269 [in English].

Berzonsky, M. (1989) Identity style: conceptualization and measurement. Journal of Adolescent Research, 4, 267-281 [in English].

Loevinger, J. (1976) Ego development: Conceptions and theories. San Fracisco: Jossey-Bass [in English].

Magnusson, D. (1996) The logic and implications of a person approach. Reports from the Department of Psychology Stockholm Univ, 817, 1004-1034 [in English].

Marcia, J. E. (1966) Development and validation of egoidentity status. Journal of Personality and Social Psychology, 3(5), 551-558 [in English].
Shamne, A.V. (2017) A variable-typology picture of the psychosocial development in adolescence. Наука і освіта. Науково-практичний журнал Південного наукового центру НАПН України. Серія «Педагогіка і психологія» - Science and education. Scientific and practical journal of the Southern Scientific Center of the National Academy of Sciences of Ukraine. Series "Pedagogy and Psychology", 7, 8387 [in English].

\section{Shamne Anzhelika}

Doctor of Psychology, associate professor, Professor of the Department of Psychology, National University of Life and Environmental Sciences of Ukraine, Kyiv (Ukraine)

\section{PSYCHOSOCIAL PERSONALITY DEVELOPMENT: CONTINUITY AND CHANGE IN ADOLESCENT, YOUTH AND ADULT AGE}

\section{ABSTRACT}

The article presents the results of the comparison of the variability of the psychosocial development of the personality in the adolescent, youth and adult age. The types of the psychosocial development of adolescents and youths are interpreted as constructive, non-constructive and destructive models of coming of age. Their substance was compared with variants (types, patterns) of the development in adulthood. The dynamics and continuity of the types of the psychosocial development and strategies for functioning adolescents, youths and adults were determined. It was revealed that the main features of continuity can be found along the lines of constructive or non-constructive development, focus on oneself or other people, self-sufficiency or dependence 
on the milieu and circumstances. The process of typing of the psychosocial development is the result of the integration of traits of the personality and the way it functions (behaves), which is inherent to it. The factors of that process were identified: regulation by the personality of his/her behavior and activities and his/her position in the system of relationships.

Keywords: type of the psychosocial development, adolescent age, young age, adult age, personality, continuity of development, locus of control, focus on oneself (on people), (non) constructive (destructive) development.

\section{Шамне Анжеліка Володимирівна}

Доктор психологічних наук, доцент,професор кафедри психологї, Національний університет біоресурсів і природокористування Украӥни, м. Київ (Украӥна)

\section{ПСИХОСОЦАЛЬНИЙ РОЗВИТОК ОСО- БИСТОСТІ: БЕЗПЕРЕРВНІСТЬ I ЗМІНИ В ПІДЛТТКОВОМУ, ЮНАЦЬКОМУ І ДОРО- СЛОМУ ВІЦІ}

\section{Анотація.}

У статті представлено порівняння варіативності психосоціального розвитку особистості в періоди підліткового віку, юнацького віку і дорослості. На першому етапі емпіричного дослідження виділено типи розвитку у підлітковому віці (автономно-самодостатній, інтернально-домінантний, доброзичливозалежний, фрустровано-кризовий) та у юнацькому віці (гармонійний, суб'єктнодомінантний, залежно-адаптивний, дезінтег- рований). В якості критеріїв типізації розвитку використовувалися особистісні, суб'єктні і соціально-поведінкові паттерни функціонування. Здійснено порівняння змісту автономно -самодостатнього та гармонійного, інтернально-домінантного та суб'єктно-домінантниого, доброзичливо-залежного та залежноадаптивного, фрустровано-кризового та дезінтегрованого типів розвитку. Їх інтерпретовано як конструктивну, неконструктивну і деструктивну моделі дорослішання. В якості основного критерія було використано ефективність розв'язання підлітками та юнаками основних задач дорослішання. Виділено дві групи детермінант оформлення типу розвитку особистості в період дорослішання: регуляція поведінки та діяльності (інтернальний/ екстернальний локус контролю; орієнтація на внутрішні чи на зовнішні критерії тощо) і позиція у системі стосунків (доброзичливість/ агресивність, егоїстична/гуманістична орієнтація тощо).

На другому етапі здійснено теоретичне узагальнення описаних у психології типів особистості і стратегій функціонування особистості у період дорослості. Аналіз здійснено на основі теорій А. Адлера, К. Хорні, Д. Марша, Е. Десі і Р. Райєна, Е. Фромма та ін. Здійснено співставлення типів (паттернів) психосоціального розвитку у період підліткового та юнацького віку з описаними типологіями розвитку у дорослості.

Аналіз показав, що між ними існує пев- 
на змістовна подібність і наступність. Основні напрями наступності від підліткового віку до дорослості проходять за наступними напрямами: становлення конструктивного (гармонійного типу) або неконструктивного (дисгармонійного типу) типу розвитку, спрямованість на себе чи на інших людей, опора на себе чи залежність від оточення і обставин. Виходячи з отриманих даних, підкреслюється, що підлітковий і юнацький вік є сензитивними до процесу оформлення індивідуального паттерну функціонування і стратегії подальшого розвитку у період дорослості. Постулюється принципова незавершеність процесу становлення особистості у підлітковому та юнацькому віці, пластичність, сенситивність, відкритість для різних можливостей і впливів.

Ключові слова: тип психосоціального розвитку, підлітковий вік, юнацький вік, дорослий вік, особистість, безперервність розвитку, локус контролю, орієнтація на себе (на людей), (не) конструктивний (деструктивний) розвиток.

\section{Шамне Анжелика Владимировна}

Доктор психологических наук, доцент, профессор кафедры психологии, Национальный университет биоресурсов и природопользования Украинь, г. Киев (Украина)

ПСИХОСОЦИАЛЬНОЕ РАЗВИТИЕ ЛИЧНОСТИ: НЕПРЕРЫВНОСТЬ И ИЗМЕНЕНИЯ В ПОДРОСТКОВОМ, ЮНОШЕСКОМ И ВЗРОСЛОМ BO3PACTE

\section{Аннотация.}

В статье представлено сравнение вариативности психосоциального развития личности в периоды подросткового возраста, юношеского возраста и взрослости. На первом этапе эмпирического исследования выделены типы развития в подростковом возрасте (автономно-самодостаточный, интернальнодоминантный, доброжелательно-зависимый, фрустрированные-кризисный) и в юношеском возрасте (гармоничный, субъектнодоминантный, зависимо-адаптивный, дезинтегрированный). В качестве критериев типизации развития использовались личностные, субъектные и социально-поведенческие паттерны функционирования. Проведено сравнение содержания автономно-самодостаточного и гармоничного, интернально-доминантного и субъектно-доминантниого, доброжелательнозависимого и зависимо-адаптивного, фрустрированно-кризисного и дезинтегрированного типов развития. Их интерпретировано как конструктивную, неконструктивную и деструктивную модели взросления современной молодежи. В качестве основного критерия были использованы эффективность решения подростками и юношами основных задач взросления. Выделены две группы детерминант оформления типа развития личности в период взросления: регуляция поведения и деятельности (интернальный / экстернальный локус контроля, ориентация на внутренние или на внешние критерии и т.д.) и позиция в 
системе отношений (доброжелательность / агрессивность, эгоистичная / гуманистическая ориентация и т.д.).

На втором этапе осуществлено теоретическое обобщение описанных в психологии типов личности и стратегий функционирования личности в период взрослости. Анализ осуществлен на основе теорий А. Адлера, К. Хорни, Д. Марша, Е. Деси и Р. Райена, Э. Фромма и др. Осуществлено сопоставление типов (паттернов) психосоциального развития в период подросткового и юношеского возраста с описанными типологиями развития во взрослости. Анализ показал, что между ними существует определенное содержательное сходство и преемственность. Основные направления преемственности от подросткового возраста к взрослости проходят по следующим направлениям: становление конструктивного (гармоничного типа) или неконструктивного (дисгармоничного типа) развития, направленность на себя или на других людей, опора на себя или зависимость от окружения и обстоятельств. Исходя из полученных данных, подчеркивается, что подростковый и юношеский возраст является сензитивными к процессу оформления индивидуального паттерна функционирования и стратегии дальнейшего развития в период взрослости. Постулируется принципиальная незавершенность процесса становления личности в подростковом и юношеском возрасте, его пластичность, сензитивность, открытость для различных возможностей и влияний.

Ключевые слова: тип психосоциального развития, подростковый возраст, юношеский возраст, взрослость, личность, непрерывность развития, локус контроля, ориентация на себя (на людей), (не) конструктивное (деструктивное) развитие.

Дата отримання статті: 21.06.2019 Дата рекомендації до друку: 25.06.2019 Дата оприлюднення: 29.06.2019 